\title{
Distribution of epiphytic bryophytes in Wroclaw in relation to urban-use complexes
}

\author{
Ewa Fudali
}

Wroclaw University of Life and Environmental Sciences, Department of Botany and Plant Ecology, pl. Grunwaldzki 24a, 50-363 Wroclaw, Poland, e-mail: ewa.fudali@upwr.edu.pl, ORCID: http://orcid.org/0000-0001-7923-8748

\begin{abstract}
Studies on epiphytic bryophyte species richness and diversity in various urban-use complexes in Wroclaw (excluding urban forests) were conducted in 2013-2016 to check the research hypothesis that, in spite of the observed phenomenon of return of bryophytic epiphytes to cities, urban parks still favor species richness and the diversity of bryophytic epiphytes in built-up areas. Epiphytes ( 38 species) were recorded in all distinguished urban-use complexes but with strongly differentiated frequency, and $64 \%$ of all the trees colonized with epiphytes were situated either along streets or inside urban green areas (32\% in each). It was shown that the highest species richness ( $89 \%$ of all the species found), bryophyte total coverage and values of the diversity indices referred to the latter complex. 20 species revealed preferences to occur mostly or exclusively on trees situated in urban parks. The second urban-use complex, which visibly affected the distribution of epiphytes, was the complex of streets; Tortula muralis occurred only on trees along streets and six other species occurred more frequently in these complexes than in others: Orthotrichum diaphanum, O. pumilum, O. pallens, Ceratodon purpureus, Syntrichia virescens, Bryum argenteum. In general, epiphytes - which were recorded on more than 20 trees - colonized a large number of phorophytes, from 12 to 33 . They also showed some tendencies to occupy trunks of some host tree species more frequently than others. Detailed data are provided.
\end{abstract}

Key words: urban bryophytes, host tree preferences, urban parks, biodiversity of rural lands, diversity indices

\section{Introduction}

In the last two decades, a return of epiphytic mosses to urban areas was recorded in some European cities, e.g. in London (Davies et al. 2006; Duckett \& Pressel 2009), Halle (Richter et al. 2009), Lisbon (Sérgio et al. 2016) and Katowice (Stebel \& Fojcik 2016). The cited research documented an increase in both the species number (e.g. 19 new species in Lisbon and 10 in Katowice) and in the number of localities, from single to numerous. Many newcomers in Lisbon were nitrophytic, such as Orthotrichum diaphanum and O. tenellum, which showed a statistically significant increase in frequency. Their present distribution was accompanied by a high increase in the level of nitrogen oxides immission from traffic (Sérgio et al. 2016). Similar observation of wide distribution in London of Orthotrichum diaphanum, in habitats from low to high levels of NOx (close to roads) was given in the paper by Davies et al. (2006). In Katowice, Stebel \& Fojcik (2016) found $O$. diaphanum and $O$. pumilum in places previously classified as "epiphytic deserts" and a decrease in the level of air pollution, especially in sulphur dioxide, was highlighted as a main factor affecting the recolonization of epiphytic bryophytes in that city; similarly to Halle (Richter et al. 2009).

Faced with these reports, the previous bryofloristical data documenting that cities were areas generally devoid of epiphytic bryophytes and this ecological group persisted only in large parks and urban forests (e.g. Schaepae 1986; Fudali 1996; Vanderpoorten 1997; Fojcik \& Stebel 2001) might seem outdated. Dymytrova (2009) found 12 epiphytic bryophyte species on trees planted along streets and 14 others - in inner parks situated in built-up area of Kyiv. Thus, more up-to-date studies on urban bryophytes and their present-day distribution in relation to habitat heterogeneity of cities (expressed through the diversity of urban-use complexes) are needed. This aspect of epiphyte distribution in cities, especially in quantitative approach, has hardly been studied in recent literature (e.g. Dymytrova 2009), although some data and general conclusions referring 
to the impact of land use on the occurrence of epiphytic bryophytes in cities were included in works by Kirmaci \& Ağcagil (2009), Richter et al. (2009), Sabovljević \& Grdović (2009), Sérgio et al. (2016) and Stebel \& Fojcik (2016).

In the period between 2000 and 2011, also in Wroclaw parks, an increase in the number of epiphytic bryophytes and their abundance was recorded (Fudali 2012). The ecological character of these species was differentiated; there were both forest specialists (e.g. Hypnum pallescens, Plagiothecium laetum, Platygyrium repens) and nitrophytic mosses preferring open areas (e.g. Orthotrichum pumilum, O. diaphanum). Since the year 2012, in the built-up part of the city, Fudali (2018) noticed a visible increase of trees colonized with epiphytic moss $O$. pumilum. Thus, the question: what is the real distribution of bryophytic epiphytes in urban area of Wroclaw and their species richness and diversity has arisen. As previous research of contemporary Wroclaw bryoflora was limited to parks and cemeteries (Berdowski 1988; Fudali 2001, 2005), in years 2013-2016, a field inventory was carried out in 455 research plots distributed through the whole area of the city (Fudali \& Szymanowski 2019). The research involved recording of epiphytic bryophyte species with estimation of their cover on trunks, identification of host tree species as well as the location of trees with epiphytes in reference to the type of urban-use complex classified according to Fudali (1996).

The goal of this paper was to characterize and compare the epiphytic bryophyte species diversity in particular urban-use complexes in Wroclaw, excluding urban forests, to check the research hypothesis that complex of urban green areas host the highest species richness, abundance and diversity of epiphytic bryophytes on the urbanized area of the city. The following questions were addressed: (i) do epiphytic bryophytes occur presently in all types of urban-use complexes?; (ii) what is the species spectrum, richness and abundance in particular urban-use complexes and are they differentiated in this respect?; (iii) do rare (in the country or in the region) epiphytic bryophyte species occur in Wroclaw and in which urban-use complex? (iv) do epiphytes found demonstrate any preferences to host-tree species and are these preferences the same in all urban-complexes? Results and conclusions are presented here.

\section{Materials and methods}

\subsection{Area characterization}

Wroclaw is one of the biggest and oldest towns in Poland, established at the end of the $12^{\text {th }}$ century. Its current area amounts to $293 \mathrm{~km}^{2}$ and is inhabited by about 640,000 people. The city is located in the south- western part of the country, in a flat area formed by the Odra River and its five tributaries, whose waters occupy about $3 \%$ of the city area (Lewicki 2014). The climate is transitional, between oceanic and continental. Winters are short (65 days) and mild. The average annual precipitation in the $20^{\text {th }}$ century was $583 \mathrm{~mm}$. The average annual temperature is $9^{\circ} \mathrm{C}$, and the annual temperature amplitude is $19.2^{\circ} \mathrm{C}$. The most frequent winds are from a westerly direction $(27.6 \%$ of days a year; the highest speed of $4.4 \mathrm{~m} / \mathrm{s}$ during winter and $3.4 \mathrm{~m} / \mathrm{s}$ in summer) and from the south $(23.1 \%)$. Within the centre of Wroclaw, an urban heat island (UHI) is detected, raising the annual mean temperature by $1^{\circ} \mathrm{C}$, and, in windless and cloudless nights, even exceeding $9^{\circ} \mathrm{C}$ (Szymanowski \& Kryza 2009).

Like most old and big cities, Wroclaw is spatially diversified in terms of land use. Almost $45 \%$ of the city area is of agriculture character with scattered buildings between gardening farms, meadows and cultivated fields. In recent decades, the latter have been partly fallowed and, more recently, systematically built-up with residential estates. A compactly built-up centrum covers about $30 \%$ of the city area. It comprises old downtown, factories, large housing estates built mostly in the period of $1960 \mathrm{~s}-1990 \mathrm{~s}$ and a strongly developed network of streets. About 17\% of the centrum surface is occupied by urban greenery consisting of four large parks and a few smaller ones, wooded sports facilities, cemeteries and walking routes. In general estimation, the communication network (streets, roads and railway tracks) covers about $9.7 \%$ of the city area; urban forests occupy circa $7.6 \%$ (Lewicki 2014).

\subsection{Sampling design}

For the research, an initial network of $100 \times 100 \mathrm{~m}$ plots (squares) was established over the whole area of Wroclaw. Next, based on a 1-m surface digital terrain model (LiDAR-originated), determining the canopy of trees, all the squares where trees existed were selected. From that set, 500 research plots were randomly drawn (Fudali \& Szymanowski 2019) and 45 - situated in urban forests - were excluded. In every research plot (found in the field using a GPS device), all trees with a girth of more than $30 \mathrm{~cm}$ (minimal limitation taken from Mežaka et al. 2008) were studied at the height range of $0.8-1.2 \mathrm{~m}$ above ground level to find presence of bryophytes. Bases of trees were excluded from the investigation, as they differ in ecological conditions from trunks and are often overgrown with competitive epigeic bryophytes (Barkman 1958; Fudali \& Wolski 2015). In total, epiphytic bryophytes were recorded on 760 trees.

Vegetation records presented here were sampled in 2013-2014 and 2016; their methodology followed the principles of Richter et al. (2009), with some modifications. On trees with bryophytes at the height section 
studied, plots of $30 \times 40 \mathrm{~cm}$ in size were established, and a list of the species and their $\%$ coverage in the plot was estimated. Altogether, 818 relevés were processed. For the results, the observed percentage coverage of the bryophyte species was converted into the size of the area covered with the species in $\left[\mathrm{dm}^{2}\right]$. Expositions of the relevés were determined with use of tourist compass. Every species presence on every trunk was regarded as one bryophyte record. Altogether, 2141 records were collected.

Species that could not readily be identified in the field were sampled for determination in the laboratory. Additionally, the tree species identity was recorded and their location in relation to the character of land use (urban-use complex) was noted. This method of determining the affiliation of trees to a particular urbanuse complex in the field was more precise than using land-use/land-cover maps, which can be inadequate in cases of plots with mixed land use. The idea of the urban-use complex identification was taken from Fudali (1996) and modified to Wroclaw spatial structure. These complexes were classified using the following criteria: the ratio of built up to open area, type of building combined with the way of the trees arrangement (arborisation type), kind of use by inhabitants (housing, communication, industrial and service buildings as place of work, recreation, agriculture). Nine main urban-use complexes, excluding urban forests whose epiphytic bryoflora was described in other article (Fudali \& Żołnierz 2019), were distinguished for the purpose of this paper:

- GrA - Complex of urban green areas (containing parks, cemeteries and afforested sportive or recreational objects) - recorded in 52 research squares (46 were situated within urban parks);

- STR - Complex of streets (trees growing in lines along streets at distances of up to $5 \mathrm{~m}$ from the street edge) - recorded in 122 research squares;

- HEs - Complex of high-rise housing settlements, built in the years 1960s-1990s, with regularly arranged lawns, usually afforested, situated both in the inner city and in suburbs - recorded in 82 research squares;

- $\mathrm{CB}$ - Complex of compact building - dense urban, industrial and service medium-high buildings (up to 4 floors), both historical and contemporary, with trees mostly singly arranged or forming small isolated groups - recorded in 99 research squares;

- RES - Complex of residential building - low (up to 2 floors) densely packed buildings with small private gardens and sporadically arranged rest-grounds with trees, situated both in the inner city and in the suburbs - recorded in 42 research squares;

- AGR - Complex of rural lands - cultivated (or fallowed) fields with scattered natural midfield groves or single trees, tree lines growing along ditches and rural settlements with gardens - recorded in 84 research squares;

- FP-Complex of deforested floodplains with single trees - recorded in 25 research squares;

- ALL - Complex of allotments, with almost exclusively fruit trees - recorded in 14 research squares;

- Rail - Complex of railway tracks - recorded in 35 research squares.

Species diversity of the urban-use complexes was assessed by the number of species and two diversity indices: the Margalef relative species richness index (R1) and Shannon diversity index $\left(H^{\prime}\right)$ (Sienkiewicz 2010). For calculations, the number of species records was used ( $\mathrm{n}$ - number of the given species' records collected in the individual urban-use complex, $\mathrm{N}$ - total number of the bryophytes' records gathered in the given urban-use complex).

The moss and liverwort nomenclature follows Ochyra et al. (2003) and Szweykowski (2006) with the exception of Rosulabryum moravicum (Podp.) Ochyra $\&$ Stebel, names of tree species were taken from Mirek et al. 2002. Specimens of bryophytes were deposited in [KRAM].

\section{Results}

\subsection{Epiphytic bryophytes' frequency, abundance and species richness in urban-use complexes}

Epiphytic bryophytes were recorded on tree trunks in all distinguished urban-use complexes but with strongly differentiated frequency (Table 1). Sixty-four $\%$ of all the trees colonized with epiphytes were situated either along streets or inside urban green areas (with equal share), quite a large number of trees with epiphytes $(18 \%)$ were also found within housing estates built between 1960-1990s. In other urban-use complexes, epiphytes on trees were found rarely and two complexes: allotments and railway tracks were found to be almost completely devoid of epiphytes.

Eighty-one \% of all records referred to three complexes: the complex of streets $(33 \%)$, the complex of urban green areas (31\%) and the complex of housing estates built between 1960s-1990s (17\%) - Table 1 .

With regard to total bryophyte coverage on trunks, the results were slightly different: the highest share was noted for the complex of urban green areas (35\%) - Table 1 . However, if bryophyte coverage in every urban-use complex was calculated per one tree trunk, the highest value of average coverage was revealed for the complexes of floodplains $\left(3.51 \mathrm{dm}^{2}\right)$ and rural lands $\left(2.72 \mathrm{dm}^{2}\right)$ not for urban parks $\left(2.03 \mathrm{dm}^{2}\right)$. Average bryophyte coverage calculated for all trees together amounted to $1.85 \mathrm{dm}^{2}$. 
Table 1. General characteristic of the epiphytic bryophytes occurrence in the individual urban-use complexes and values of the Margalef relative species richness index (R1) and Shannon diversity index $\left(H^{\prime}\right)$

\begin{tabular}{lcrrrrr}
\hline Type of urban-use complex & $\begin{array}{l}\text { No. of } \\
\text { trees } \\
\text { with } \\
\text { epiphytes }\end{array}$ & $\begin{array}{l}\text { No. of } \\
\text { epiphytic } \\
\text { bryophyte } \\
\text { records }\end{array}$ & $\begin{array}{l}\text { Total } \\
\text { bryophyte } \\
\text { cover } \\
{\left[\mathrm{dm}^{2}\right]}\end{array}$ & $\begin{array}{l}\text { No. of } \\
\text { epiphytic } \\
\text { bryophyte } \\
\text { species }\end{array}$ & R1 & $H^{\prime}$ \\
\hline Complex of urban green areas & 243 & 669 & 495.7 & 34 & 11.6796 & 2.4885 \\
Complex of streets & 243 & 711 & 397.5 & 22 & 7.3636 & 2.0312 \\
Complex of housing settlements built & 134 & 366 & 203 & 19 & 7.0217 & 2.0197 \\
between 1960s - 1990s. & 44 & 90 & 44.6 & 16 & 7.6756 & 2.2686 \\
Complex of compact urban building & 12 & 46 & 10.6 & 10 & 5.4127 & 1.5659 \\
Complex of residential building & 50 & 126 & 136.2 & 21 & 9.5221 & 2.3974 \\
Complex of rural lands & 31 & 127 & 108.8 & 20 & 9.0313 & 2.1244 \\
Complex of floodplains & 1 & 1 & 0.2 & 1 & 0 & 0 \\
Complex of allotments & 2 & 5 & 6.8 & 3 & 2.8613 & 1.0549 \\
Complex of railway tracks & 760 & 2141 & 1403.4 & 38 & & \\
$\sum$ & & & & & & \\
\hline
\end{tabular}

In total, 38 epiphytic bryophyte species were recorded. The highest species richness $(89 \%$ of all the species found) and values of the Margalef relative species richness index and the Shannon diversity index were recorded for the complex of urban green areas - Table 1. Quite rich in species, at a similar level of species number, were also three other complexes: streets (22 species $-58 \%)$, rural lands $(21-55 \%)$ and floodplains $(20-53 \%)$. Values of the diversity indices calculated for these three complexes were the highest for the complex of rural lands.

Bryophytes were not evenly distributed around trunks, most of the relevés occurred with western (43\%) or northern (34\%) expositions, and fifteen $\%$ of relevés occupied the sector from north-eastern to eastern exposition, which, only partly, corresponded with directions of most frequent winds.

\subsection{Species composition of epiphytic bryophyte flora in particular urban-use complexes}

Among 38 epiphytic species recorded, only seven were noted on more than 100 trees and they made up $79 \%$ of all records (Table 2). Total coverage of these species amounted to $1243.4 \mathrm{dm}^{2}$, reaching $88 \% .24$ species occurred less than 20 times, including 16 recorded on maximum 5 trunks and their total coverage amounted to $32.53 \mathrm{dm}^{2}(2.3 \%)$.

Three of the most frequent species: Orthotrichum diaphanum, Hypnum cupressiforme and Amblystegium serpens were recorded in all the urban-complexes, while two other frequent species, Orthotrichum pumilum and Brachythecium rutabulum - in almost all (without railways); however, with differentiated share there (Table 2). Most of the epiphytic bryophyte spe- cies appeared only in some urban-use complexes, which resulted in the differentiated species compositions of their epiphytic bryoflora. Regarding the presence and percentage incidence of the species in particular urbanuse complexes, the group of epiphytes with a tendency to occur exclusively or mostly in the complex of urban parks has emerged - it contained 20 species, both rarely noted and limited in their occurrence to parks (13) as well as frequent and widespread in the city, e.g. Hypnum cupressiforme, Brachythecium rutabulum, Dicranoweisia cirrata, Orthotrichum affine, Rosulabryum moravicum, Brachytheciastrum velutinum. The second urban-use complex which visibly affected the distribution of epiphytes was the complex of streets Tortula muralis occurred only on trees along streets and six other species showed a tendency to colonize mostly them: Orthotrichum diaphanum, O. pumilum, Ceratodon purpureus, Syntrichia virescens, Bryum argenteum, O. pallens. Epiphytic bryoflora of the rural lands complex contained some species which, in the built-up area of the city, were found either exclusively or with high percentage in parks, e.g. Aulacomnium androgynum, Orthodicranum montanum, O.tauricum, Dicranum scoparium, Platygyrium repens, Hypnum pallescens, Plagiothecium laetum. Within complexes dominated by buildings, altogether 21 species were recorded there but only 8 of them were found in every of these complexes.

\subsection{Tree species colonized in various urban-use complexes}

The individual urban-use complexes differed in the number of tree species colonized by epiphytic bryophytes (Fig. 1). The greatest species richness of host 
Table 2. Percentage incidence of epiphytic bryophyte species in the individual urban-use complexes and their general frequency (the number of species records) and abundance (total species coverage). Explanation of the urban-use complexes' symbols in the text (chapter: Materials and methods)

\begin{tabular}{|c|c|c|c|c|c|c|c|c|c|c|}
\hline & \multirow{2}{*}{$\begin{array}{c}\text { Total } \\
\text { species } \\
\text { cover } \\
{\left[\mathrm{dm}^{2}\right]}\end{array}$} & \multirow{2}{*}{$\begin{array}{l}\text { No. } \\
\text { of the } \\
\text { species } \\
\text { records }\end{array}$} & \multicolumn{8}{|c|}{$\%$ of the species records } \\
\hline & & & GrA & STR & HEs & $\mathrm{CB}$ & RES & AGR & FP & Rail \\
\hline Orthotrichum diaphanum Schrad. ex Brid. & 583.9 & 471 & 13 & 44.6 & 29 & 4 & 4 & 2 & 3 & 0.4 \\
\hline Hypnum cupressiforme Hedw. & 378.3 & 324 & 39 & 23 & 12.6 & 5 & 0.3 & 11.4 & 8 & 0.6 \\
\hline Amblystegium serpens (Hedw.) Schimp. & 88.1 & 273 & 29.7 & 31 & 16 & 6 & 3 & 5 & 8 & 1 \\
\hline Orthotrichum pumilum Sw. & 26.3 & 238 & 20 & 45 & 22.3 & 4 & 2 & 3 & 4 & 0 \\
\hline Brachythecium rutabulum (Hedw.) Schimp. & 46.5 & 144 & 35 & 24 & 22 & 4.5 & 3.5 & 3 & 8 & 0 \\
\hline Ceratodon purpureus (Hedw.) Brid. & 18.2 & 119 & 17 & 60 & 15 & 5 & 1.5 & 0 & 1.5 & 0 \\
\hline Dicranoweisia cirrata (Hedw.) Lindb. & 102.1 & 113 & 77 & 10 & 2 & 1 & 0 & 7 & 3 & 0 \\
\hline Platygyrium repens (Brid.) Schimp. & 97.7 & 82 & 67 & 5 & 2 & 0 & 0 & 22 & 4 & 0 \\
\hline Orthotrichum affine Schrad. ex Brid. & 7.4 & 56 & 41 & 23 & 9 & 6 & 7 & 2 & 12 & 0 \\
\hline Rosulabryum moravicum (Podp.) Ochyra \& Stebel & 8.4 & 44 & 57 & 7 & 4 & 2 & 0 & 2 & 28 & 0 \\
\hline Syntrichia virescens (De Not.) Ochyra & 3.3 & 41 & 2.5 & 76 & 7 & 5 & 2.5 & 0 & 7 & 0 \\
\hline Bryum argenteum Hedw. & 1.1 & 39 & 2.5 & 69 & 21 & 5 & 0 & 0 & 2.5 & 0 \\
\hline Brachytheciastrum velutinum (Hedw.) Ignatov \& Huttunen & 5.3 & 36 & 56 & 17 & 8 & 8 & 0 & 3 & 8 & 0 \\
\hline Orthotrichum pallens Bruch ex Brid. & 5.1 & 31 & 13 & 52 & 29 & 0 & 3 & 3 & 0 & 0 \\
\hline Hypnum pallescens (Hedw.) P. Beauv. & 3.9 & 19 & 64 & 5 & 5 & 0 & 0 & 21 & 5 & 0 \\
\hline Pylasia polyantha (Hedw.) Schimp. in Bruch & 3.8 & 15 & 46 & 20 & 0 & 6.3 & 6.3 & 6.3 & 13 & 0 \\
\hline Orthotrichum anomalum Hedw. & 0.3 & 13 & 31 & 31 & 31 & 7 & 0 & 0 & 0 & 0 \\
\hline Dicranum scoparium Hedw. & 1.4 & 11 & 36 & 9 & 0 & 0 & 0 & 46 & 9 & 0 \\
\hline Leskea polycarpa Hedw. & 3 & 11 & 27.3 & 27 & 9.5 & 0 & 0 & 27.3 & 9.5 & 0 \\
\hline Lophocolea heterophylla (Schrad.) Dumort. & 4.1 & 10 & 50 & 0 & 10 & 0 & 0 & 30 & 10 & 0 \\
\hline Orthodicranum tauricum (Sapjegin) Smirnova & 2.6 & 7 & 85.7 & 0 & 0 & 0 & 0 & 14.3 & 0 & 0 \\
\hline Orthodicranum montanum (Hedw.) Loeske & 6.1 & 6 & 50 & 0 & 0 & 0 & 0 & 50 & 0 & 0 \\
\hline Dryptodon pulvinatus (Hedw.) Brid. & 0.04 & 5 & 0 & 40 & 20 & 40 & 0 & 0 & 0 & 0 \\
\hline Plagiothecium laetum Schimp. & 2.7 & 5 & 60 & 0 & 0 & 0 & 0 & 20 & 20 & 0 \\
\hline Aulacomnium androgynum (Hedw.) Schwägr. & 1 & 4 & 50 & 0 & 0 & 0 & 0 & 50 & 0 & 0 \\
\hline Herzogiella seligeri (Brid.) Z. Iwats. & 0.3 & 4 & 50 & 0 & 0 & 0 & 0 & 0 & 50 & 0 \\
\hline Radula complanata (L.) Dumort. & 0.4 & 4 & 100 & 0 & 0 & 0 & 0 & 0 & 0 & 0 \\
\hline Brachythecium salebrosum (Hoffm. ex Weber \& Mohr) Schimp. & 0.8 & 3 & 100 & 0 & 0 & 0 & 0 & 0 & 0 & 0 \\
\hline Plagiomnium affine (Blandow ex Funck) T.J. Kop. & 0.1 & 2 & 100 & 0 & 0 & 0 & 0 & 0 & 0 & 0 \\
\hline Pohlia nutans (Hedw.) Lindb. & 0.4 & 2 & 50 & 50 & 0 & 0 & 0 & 0 & 0 & 0 \\
\hline Tortula muralis Hedw. & 0.01 & 2 & 0 & 100 & 0 & 0 & 0 & 0 & 0 & 0 \\
\hline Bryum caespiticium Hedw. & 0.1 & 1 & 0 & 0 & 0 & 100 & 0 & 0 & 0 & 0 \\
\hline Metzgeria conjugata Lindb. & 0.2 & 1 & 100 & 0 & 0 & 0 & 0 & 0 & 0 & 0 \\
\hline Mnium hornum Hedw. & 0.1 & 1 & 0 & 0 & 0 & 0 & 0 & 100 & 0 & 0 \\
\hline Plagiothecium curvifolium Schliep. ex Limpr. & 0.1 & 1 & 100 & 0 & 0 & 0 & 0 & 0 & 0 & 0 \\
\hline Plagiothecium denticulatum (Hedw.) Schimp. & 0.1 & 1 & 100 & 0 & 0 & 0 & 0 & 0 & 0 & 0 \\
\hline Sanionia uncinata (Hedw.) Loeske & 0.1 & 1 & 100 & 0 & 0 & 0 & 0 & 0 & 0 & 0 \\
\hline Syntrichia papillosa (Wilson) Jur. & 0.01 & 1 & 100 & 0 & 0 & 0 & 0 & 0 & 0 & 0 \\
\hline$\sum$ & 1403.4 & 2141 & & & & & & & & \\
\hline
\end{tabular}

trees colonized was found in the complex of urban green areas and the complex of streets.

Altogether, epiphytic bryophytes were found on trunks of 33 tree species; 16 of them were colonized by bryophytes rarely, no more than 10 times. These were: Sambucus nigra ( 8 specimens inhabited by epiphytic bryophytes), Populus alba (7), Alnus glutinosa (6), Juglands regia (6), Acer palmatum (4), Crataegus monogyna (4), Pyrus communis (4), Prunus avium (4), Populus $\times$ berolinensis (3), P. tremula (3), Carpinus betulus (2), Quercus petraea (2), Fagus sylvatica (1), Morus alba (1), Padus serotina (1) and Platanus acerifolia (1). More than 10 individuals with epiphytes were registered in reference to 17 tree species and their records made up together $92.5 \%$ of all (Fig. 2).

The analysis of the number of various tree species' individuals colonized by bryophytes in particular urbanuse complexes showed that almost all trunks with epiphytes of Betula pendula were situated in the complex of urban green areas, while most colonized trunks of 


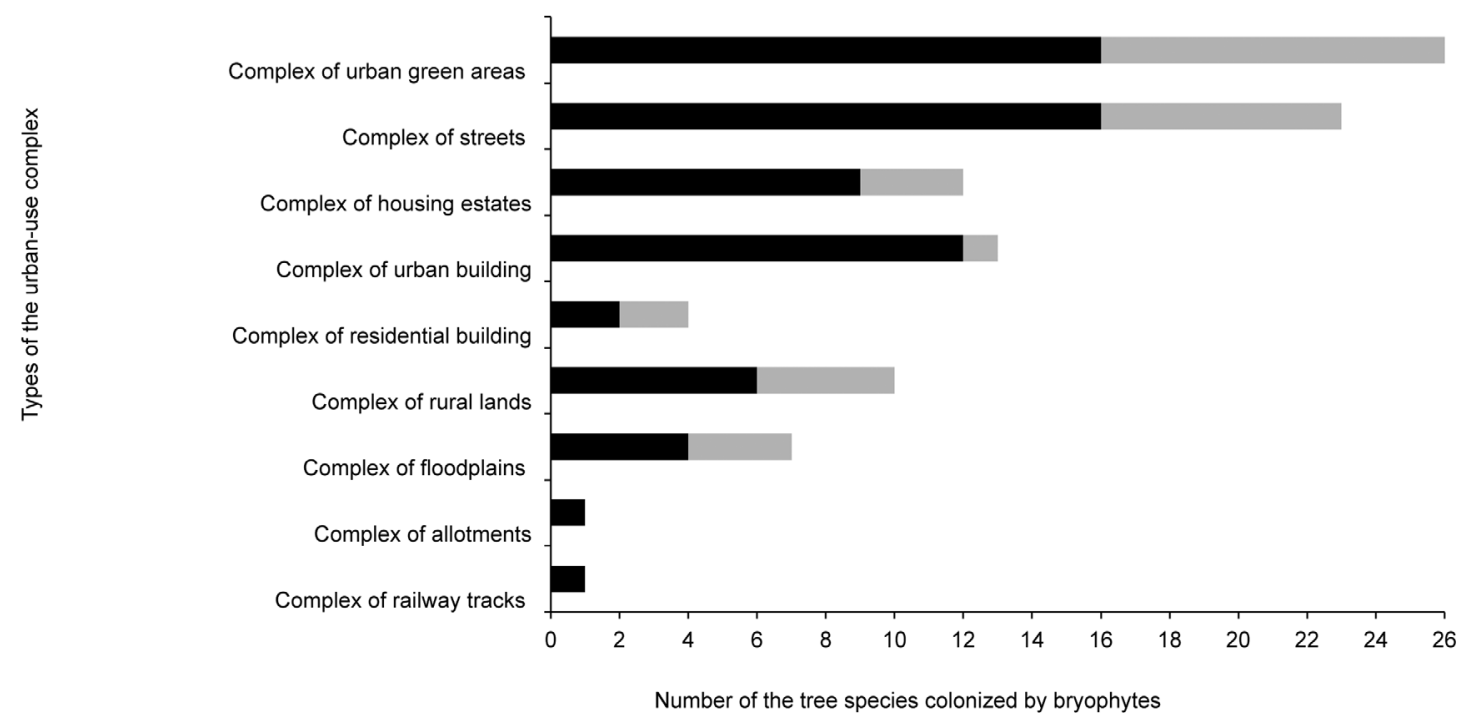

Fig. 1. Number of the tree species colonized by epiphytic bryophytes recorded in the particular urban-use complexes

Explanations: - tree species with more than 10 individuals recorded with bryophytes, - tree species with less than 10 individuals recorded with bryophytes

Tilia cordata, T. platyphyllos, Populus italica, Quercus rubra and Fraxinus excelsior were registered either in urban parks or on trees growing along streets. Trunks of other tree species inhabited by epiphytic bryophytes occurred in a greater number of urban-use complexes but with differentiated frequency there, too (Fig. 2). It was revealed that, in the complex of urban green areas, epiphytes were found most frequently on the trunks

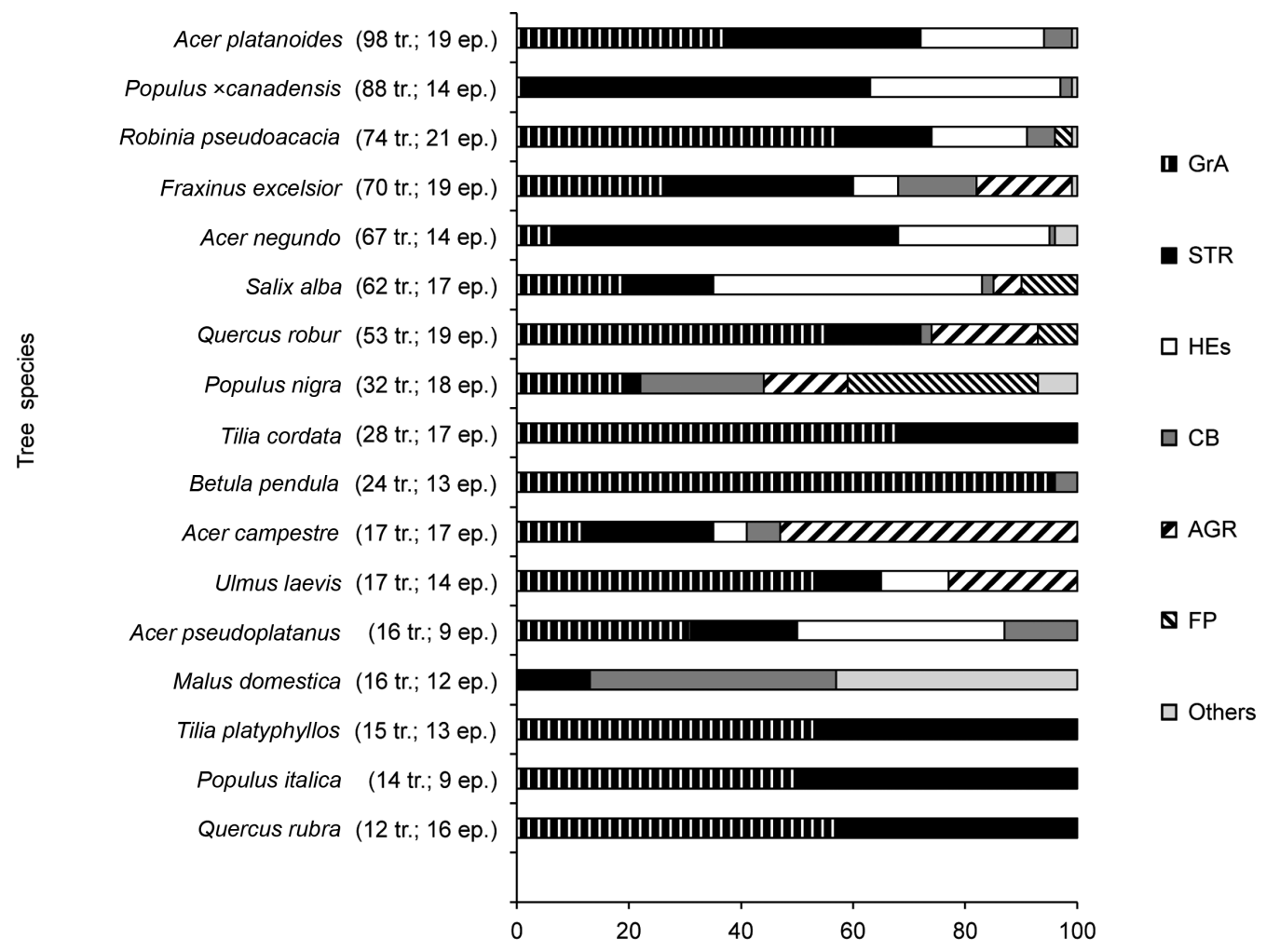

$\%$ of the tree individuals with the epiphytic bryophytes

Fig. 2. Percentage incidence of host-tree individuals colonized with epiphytes in the individual urban-use complexes (only tree species with more than 10 epiphytic individuals)

Explanations: in brackets - the number of tree trunks with epiphytes ( $t r$.) and, after semicolon, the number of the epiphytic bryophyte species recorded ( $e p$.); symbols of the urban-use complexes explained in the text (chapter: Materials and methods) 
Table 3. Total number of records (in all urban-use complexes together) of the most frequent epiphytic bryophyte species (noted at least 10 times) on the host-tree species (only those tree species with more than 10 individuals with epiphytes)

\begin{tabular}{|c|c|c|c|c|c|c|c|c|c|c|c|c|c|c|c|c|c|c|}
\hline & $\begin{array}{c}\text { No. of } \\
\text { tree } \\
\text { species } \\
\text { colonized }\end{array}$ & Ac & An & Apl & Aps & $\mathrm{Bp}$ & $\mathrm{Fe}$ & $\mathrm{Md}$ & $\mathrm{Pc}$ & $\mathrm{Pi}$ & Pn & Qro & Qru & $\mathrm{Rp}$ & $\mathrm{Sa}$ & $\mathrm{Tc}$ & $\mathrm{Tp}$ & U1 \\
\hline Orthotrichum diaphanum & 33 & . & 62 & 70 & 8 & . & 50 & 15 & 67 & 14 & 35 & 5 & 3 & 33 & 51 & 6 & 3 & 8 \\
\hline Hypnum cupressiforme & 28 & 12 & 11 & 21 & 2 & 9 & 38 & 3 & 14 & 6 & 25 & 26 & 4 & 38 & 36 & 14 & 11 & 8 \\
\hline Amblystegium serpens & 29 & 12 & 24 & 39 & 3 & 1 & 23 & 10 & 25 & . & 23 & 6 & 2 & 27 & 32 & 4 & 5 & 4 \\
\hline Orthotrichum pumilum & 26 & 5 & 29 & 45 & 6 & . & 28 & 5 & 25 & 9 & 11 & 7 & 2 & 20 & 21 & 2 & 4 & 2 \\
\hline Brachythecium rutabulum & 27 & 9 & 10 & 10 & 2 & 1 & 8 & . & 17 & 1 & 12 & 6 & 1 & 21 & 27 & 6 & 1 & 1 \\
\hline Ceratodon purpureus & 22 & 2 & 7 & 28 & . & 3 & 5 & 2 & 16 & . & 11 & 1 & 1 & 15 & 3 & 4 & 3 & 2 \\
\hline Dicranoweisia cirrata & 16 & 2 & . & 6 & . & 24 & 5 & . & . & . & 2 & 22 & 7 & 29 & 1 & 6 & . & 2 \\
\hline Platygyrium repens & 21 & 5 & . & 7 & 1 & 1 & 2 & . & 1 & . & 4 & 12 & 2 & 8 & 9 & 5 & 5 & 4 \\
\hline Orthotrichum affine & 19 & 1 & 1 & 5 & . & . & 5 & 2 & 3 & . & 1 & 3 & 1 & 3 & 20 & . & 1 & 1 \\
\hline Rosulabryum moravicum & 14 & 3 & 1 & 1 & . & . & 5 & . & . & . & 7 & 1 & . & 14 & 3 & 1 & 2 & 1 \\
\hline Syntrichia virescens & 14 & . & 3 & 5 & . & . & 5 & 1 & 8 & 4 & 5 & 1 & 1 & 3 & . & . & 1 & 1 \\
\hline Bryum argenteum & 13 & . & 3 & 11 & 1 & . & 5 & . & 8 & 3 & 2 & . & . & 1 & 1 & . & 1 & . \\
\hline Brachytheciastrum velutinum & 14 & 1 & 4 & 6 & 2 & . & 5 & . & 1 & . & 3 & 1 & 1 & 3 & 1 & 4 & 3 & . \\
\hline Orthotrichum pallens & 12 & 1 & 9 & 6 & . & 1 & 1 & 1 & 4 & . & . & . & 1 & 1 & 4 & . & 1 & . \\
\hline Hypnum pallescens & 9 & . & 1 & 1 & . & . & . & . & . & . & 1 & . & . & 5 & 4 & 1 & . & 1 \\
\hline Pylaisia polyantha & 8 & . & . & 4 & . & . & 1 & 2 & . & 3 & 1 & . & . & 1 & 2 & . & . & . \\
\hline Orthotrichum anomalum & 6 & 1 & 1 & . & . & . & 4 & 1 & 4 & . & . & . & . & 2 & . & . & . & . \\
\hline Dicranum scoparium & 9 & . & . & 1 & . & 2 & 1 & . & . & . & 1 & 1 & 1 & 1 & . & . & . & 1 \\
\hline Leskea polycarpa & 8 & 1 & . & 1 & . & . & 2 & . & . & . & . & . & 1 & . & 2 & 1 & . & 2 \\
\hline Lophocolea heterophylla & 4 & . & . & . & . & 3 & . & . & . & . & . & 5 & . & . & . & . & . & . \\
\hline
\end{tabular}

Explanations: Ac - Acer campestre, An - Acer negundo, Apl - Acer platanoides, Aps - Acer pseudoplatanus, $\mathrm{Bp}$ - Betula pendula, $\mathrm{Fe}-$ Fraxinus excelsior, $\mathrm{Md}-$ Malus domestica, Pc - Populus ×canadensis, Pi - Populus italica, Pn - Populus nigra, Qro - Quercus robur, Qru - Quercus rubra, Rp - Robinia pseudoacacia, $\mathrm{Sa}$ - Salix alba, Tc - Tilia cordata, $\mathrm{Tp}$ - Tilia platyphyllos, U1 - Ulmus laevis

of: Robinia pseudoacacia, Acer platanoides, Quercus robur and Betula pendula; in the complex of streets on: Populus $\times$ canadensis, Acer negundo, A. platanoides and Fraxinus excelsior; in the complex of high-rise housing settlements, built in the period from 1960s1990s, on: Populus $\times$ canadensis, Salix alba and Acer platanoides; in the complex of rural lands on: Fraxinus excelsior, Quercus robur and Acer campestre; and in the complex of floodplains on: Salix alba, Populus nigra, P. alba and Quercus robur (Fig. 2).

\subsection{Preferences of more frequent epiphytes to occupy selected tree species}

In general, epiphytes which were recorded more frequently than 20 times colonized a large number of tree species, from 12 to 33 (Table 3). They also showed some tendencies to occupy trunks of some host tree species more frequently than others. Preferences to occur on trunks of maple Acer platanoides were recorded for: Orthotrichum diaphanum, O. pumilum, Amblystegium serpens and Ceratodon purpureus; on oak Quercus robur - for Dicranoweisia cirrata, Lophocolea heterophylla and Platygyrium repens; on Robinia pseudoacacia - for Hypnum cupressiforme,
Dicranoweisia cirrata, Rosulabryum moravicum and Brachythecium rutabulum; on Salix alba - for Orthotrichum affine, $O$. diaphanum, Brachythecium rutabulum, Hypnum cupressiforme and Amblystegium serpens; on Populus $\times$ canadensis - for Orthotrichum diaphanum, O. anomalum, Syntrichia virescens and Bryum argenteum; on Betula pendula - for Dicranoweisia cirrata and Lophocolea heterophylla.

Analysis of the frequency of bryophytic epiphytes on various host-tree species in individual urban-use complexes showed some differences in their trends to occupy selected phorophytes depending on the type of land use (Table 4). It was evidenced that in parks, Orthotrichum diaphanum occurred most frequently on trunks of Acer negundo, while within housing estates - on Salix alba and Populus $\times$ canadensis and along streets - on the latter and Acer platanoides; Amblystegium serpens colonized mostly trunks of Robinia pseudoacacia in the complex of urban green areas but of Canadian poplar and maple ash in the complex of streets. Hypnum cupressiforme also preferred trunks of black locust in urban parks but of Norway maples and white willows growing along streets. Orthotrichum pumilum occurred with the highest frequency on Norway maples in all three analysed complexes but other host 
Table 4. Percentage incidence of the most widespread epiphytic bryophytes on the trunks of host tree species (only those with share more than $10 \%$ ) in three urban-use complexes

\begin{tabular}{|c|c|c|c|c|c|c|}
\hline \multirow{2}{*}{$\begin{array}{c}\text { Epiphytic } \\
\text { bryophyte species }\end{array}$} & \multicolumn{2}{|c|}{$\begin{array}{c}\text { Complex of green urban } \\
\text { areas }\end{array}$} & \multicolumn{2}{|l|}{ Complex of streets } & \multicolumn{2}{|c|}{ Complex of housing estates } \\
\hline & tree species & $\%$ & tree species & $\%$ & tree species & $\%$ \\
\hline \multirow{4}{*}{$\begin{array}{l}\text { Orthotrichum } \\
\text { diaphanum }\end{array}$} & Acer negundo & 22 & Acer platanoides & 19 & Salix alba & 22 \\
\hline & Fraxinus excelsior & 15 & Populus $\times$ canadensis & 19 & Populus $\times$ canadensis & 19 \\
\hline & Robinia pseudoacacia & 13 & Acer negundo & 16 & Robinia pseudoacacia & 13 \\
\hline & Acer platanoides & 13 & & & & \\
\hline \multirow{5}{*}{$\begin{array}{l}\text { Hypnum } \\
\text { cupressiforme }\end{array}$} & Robinia pseudoacacia & 19 & Acer platanoides & 20 & & \\
\hline & Acer platanoides & 13 & Salix alba & 19 & & \\
\hline & & & Robinia pseudoacaccia & 16 & any tendencies & \\
\hline & & & Populus $\times$ canadensis & 15 & & \\
\hline & & & Fraxinus excelsior & 12 & & \\
\hline \multirow{3}{*}{$\begin{array}{l}\text { Amblystegium } \\
\text { serpens }\end{array}$} & Robinia pseudoacacia & 21 & Populus $\times$ canadensis & 21 & & \\
\hline & Salix alba & 11 & Acer negundo & 19 & any tendencies & \\
\hline & & & Acer platanoides & 17 & & \\
\hline \multirow{4}{*}{$\begin{array}{l}\text { Orthotrichum } \\
\text { pumilum }\end{array}$} & Acer platanoides & 25 & Acer platanoides & 17 & Acer platanoides & 23 \\
\hline & Robinia pseudoacacia & 21 & Acer negundo & 15 & Populus $\times$ canadensis & 17 \\
\hline & Salix alba & 12 & Populus $\times$ canadensis & 13 & Acer negundo & 13 \\
\hline & & & Fraxinus excelsior & 12 & Robinia pseudoacacia & 13 \\
\hline \multirow{3}{*}{$\begin{array}{l}\text { Brachythecium } \\
\text { rutabulum }\end{array}$} & Robinia pseudoacacia & 20 & Populus $\times$ canadensis & 31 & Salix alba & 25 \\
\hline & Salix alba & 20 & Acer negundo & 17 & Populus $\times$ canadensis & 19 \\
\hline & & & & & Robinia pseudoacacia & 15 \\
\hline
\end{tabular}

tree species accompanying were different. In the case of Brachythecium rutabulum, a similar tendency to occupy trunks of Robinia pseudoacacia and Salix alba were recorded in the complex of urban green areas and the complex of housing estates, while to trunks of Populus $\times$ canadensis and Acer negundo - along streets.

\section{Discussion}

In general estimation, in the area of Wroclaw (without urban forests), the epiphytic bryophyte vegetation revealed neither high coverage nor frequency; epiphytes colonized only $4.1 \%$ of trees available (Fudali \& Szymanowski 2019) and, on average, bryophytes covered no more than $15.4 \%$ of the plot surface. But the recorded species number (38 taxa) was quite rich, when compared with reports from built-up area of London (14 species - Davies et al. 2006 ), Belgrade (19 - Sabovljević \& Grdović 2009), Halle (21 - Richter et al. 2009), Kyiv (20 - Dymytrova 2009) and Lisbon (45 - Sérgio et al. 2016).

In reference to the recent bryofloristical data from Wroclaw urban forests (Fudali \& Żołnierz 2019), altogether 21 species showed differentiated distribution; 12 were noted exclusively in these forests and 9 -recorded only out of them. Hypnum cupressiforme was one of the most frequent epiphytic bryophytes in both compared parts of Wroclaw, but the share of its records in the deforested area was much lower (15\%) than in urban forests $(27 \%)$.

On the built-up area of Wroclaw, epiphytic bryophytes were recorded both in urban parks, as expected (Fudali 2012) and in other urban-use complexes. However, the highest number of species, bryophyte total coverage and values of the diversity indices referred to the complex of urban green areas. It was determined that 20 species (more than half recorded during studies) showed preferences to occur mostly or exclusively on trees situated in urban parks. Among these species, there were some rare in the environs of Wroclaw: Hypnum pallescens, Orthodicranum tauricum, O. montanum, Plagiomnium laetum, Radula complanata, Metzgeria conjugata, Sanionia uncinata, Syntrichia papillosa (Fudali 1998; Fudali \& Żołnierz 2019). Thus, the research hypothesis formulated in the introduction cannot be rejected and, undoubtedly, urban parks remain enclaves of epiphytic bryophytes species richness and diversity in urbanized area of Wroclaw. Few reports from other cities seem to confirm this thesis, e.g. from the number of 19 species found altogether in Belgrade's built-up areas, 16 occurred only in urban parks and other green surfaces (Sabovljević \& Grdović 2009). The same was observed in Aydin (Kirmaci \& Ağcagil 2009), where out of 18 species registered on built-up areas, as many as 15 were limited to urban green areas. It should be highlighted that Wroclaw parks are situated 
close to compactly built-up city centrum and surrounded with urban buildings; some of them were established on former cemeteries or riverside woodlands, but nowadays they are not connected with urban forests (Fudali 2001).

Research showed that trees growing in the complex of streets hosted, surprisingly often, epiphytic bryophytes (33\% of all the records), but the species richness, total bryophyte coverage and average bryophyte coverage per trunk were much lower than in parks. Most records from the complex of streets referred to three species, very frequent in built-up areas, such as Orthotrichum diaphanum, O. pumilum and Ceratodon purpureus. At the same time, rare epiphytic species in Poland Syntrichia virescens (R category of threat - Żarnowiec et al. 2004) was found mostly on trees situated along streets. The latter also harboured three other species rarely noted in built-up areas of Wroclaw: Orthotrichum affine, Pylaisia polyantha and Leskea polycarpa. These results correspond partly with the reports by Davies et al. (2006), Richter et al. (2009), Dymytrova (2009) and Sérgio et al. (2016).

Among three complexes comprising various types of urban building, two complexes characterized by small share of trees, and often singly planted (the complex of residential building and the complex of compact urban building which comprises urban, industrial and service medium-tall buildings) were very poor in the epiphytes and the latter occurred on a small number of trees there. They can be recognised as almost "epiphytic bryophyte deserts". That contrasts with data collected within the complex of high-rise housing settlements, built in 1960s-1990s (typical for many Polish cities ruined during the Second World War), which appeared to be quite rich in the epiphytic bryophytes species and a large number of trees colonized by bryophytes was recorded there. A characteristic element of the spatial structure of these settlements are regularly distributed relatively large lawns with groups of trees. That illustrates that arborisation system could influence the epiphytic bryophytes diversity and distribution on built-up areas. Such suggestion was earlier formulated by Sérgio et al. (2016).

Almost all the epiphytic species found in the complexes of urban building were collected from trees along streets, too. Bryofloristical data from Kyiv (Dymytrova 2009) also showed high floristic similarity between built-up areas and streets. But in contrast to Wroclaw, the most frequent species in these urban-use complexes was Orthotrichum pumilum, while $O$. diaphanum (dominating in these complexes in Wroclaw) was almost non-existent; also Ceratodon purpureus was not frequent, while relatively high frequency was shown by Pylaisia polyantha and Leskea polycarpa, sporadically noted species in these complexes in Wroclaw. The number of species was much smaller in the discussed types of land use in Kyiv than in Wroclaw. One of the reasons for these differences might be various compositions of dendroflora in the cities compared. The most common tree species along streets in Kyiv were Tilia cordata, Acer platanoides and Populus ssp. These tree species occurred frequently also in Wroclaw but in the latter, epiphytic bryophytes revealed some preferences also to other phorophytes, such as Acer negundo, A. pseudoplatanus, Fraxinus excelsior and Salix alba, the tree species very abundant on the builtup area of Wroclaw, too (Fudali 2017 unpublished).

The question about preferences of epiphytes in relation to host trees in cities finds various answers. Richter et al. (2009) found that in Halle tree species identity was an insignificant factor in the model explaining bryophyte richness and coverage, while Fudali \& Szymanowski (2019) showed a distinctive bryofloristic dissimilarity of such species of trees as Acer negundo, Populus $\times$ canadensis, Robinia pseudoacacia, Quercus robur and Salix alba in Wroclaw. A conclusion that distribution of epiphytes depends on the variety of phorophytes was also formulated for Kyiv (Dymytrova 2009) and Katowice (Stebel \& Fojcik 2016).

Quite new aspect of the problem discussed was evidenced recently by Fudali (2018) who noticed that preferences of Orthotrichum pumilum to host tree changed along the transect from urban forests to city centrum in spite of similar availability of the tree species analyzed. She speculated that a reason might be subtle changes in properties of tree barks due to air pollutants making some tree species less available for colonization in the city centrum in comparison to suburbs or urban forests. The presented research documented that, in the case of most widespread epiphytic bryophytes, other tree species were more often colonized by them in parks than along streets or within housing estates. Unfortunately, during field studies the "tree species offer" was not determined with reference to the urban-use complexes, so uneven availability of tree species can not be rejected as one of the reasons of the observed differences. But the listed phorophytes (see Table 4) belonged to the most frequent tree species in Wroclaw (Fudali 2017 unpublished). It seems probable that microclimatic differences (especially, the available humidity affected the tree bark) between parks and built-up areas, combined with differentiated level of air pollution in these three urban-complexes, might partly explain the observed differences in the epiphyte frequency on the phorophytes in particular complexes. It was documented by Fojcik et al. (2015) that $\mathrm{pH}$ value of poplar bark differed depending on the tree localization in relation to polluted areas in Katowice and this corresponded with the presence or absence of epiphytes. Tree bark in city centers is often affected by alkaline dust contamination as evidenced by the presence of 
calcicolous epilithic species, such as Tortula muralis, Dryptodon pulvinatus and Bryum argenteum (eg. Fudali 2006; Sérgio et al. 2016).

In Wroclaw, epiphytic bryophytes were recorded also on open undeveloped areas, which cover almost half of the city area (complexes of rural lands and of floodplains), but the number of colonized trees was not large (11\% of all). However, these complexes distinguished themselves with higher values of diversity indexes than in built-up areas (excluding urban parks) and the highest average bryophyte cover per tree trunk. The latter was also the highest in floodplains in Halle (Richter et al. 2009). It was observed that, among species recorded in the rural lands, there was a group of seven taxa which, in the built-up areas, were found either exclusively or with higher percentage in parks and these were forests species (Fudali \& Żołnierz 2019). This suggests that trees growing in the complex of rural lands could serve as a gangway in the spread of forest epiphytic bryophytes on urban areas. Thus, preservation of midfield groves, postulated in the works on the conservation of biodiversity in agricultural landscapes (e.g. Symonides
2010; Gamrat 2012), may also be important in relation to urban biodiversity protection.

\section{Conclusions}

Habitat heterogeneity of cities expressed through diversity of urban-use complexes that differ between one another in the intensity and type of urban pressure, size of land transformation, level of pollution as well as the quantity of trees and their arrangement and species composition is reflected in epiphytic bryophyte richness, diversity and distribution in the city. Although urbanized areas cease to be deserts in terms of the presence of epiphytes, as reported from some European cities, urban parks still tend to be these urban habitats that favor species richness and diversity of bryophytic epiphytes in built-up areas.

In order to conserve this aspect of urban biodiversity, it is necessary to take care of these habitats and tree specimens which host epiphytic bryophytes, as well as to ensure that tree species preferred by epiphytes are planted regularly.

\section{References}

Barkman J. J. 1958. Phytosociology and ecology of cryptogamic epiphytes. 628 pp. Van Gorcum \& Comp., Assen.

Berdowski W. 1988. Flora mchów Ogrodu Botanicznego we Wrocławiu. Acta Univ. Wratisl. 974, Pr. Bot. 29: 47-59.

Davies L., Bates J. W., Bell J. N. B., James P. W. \& Purvis O. W. 2006. Diversity and sensitivity of epiphytes to oxides of nitrogen in London. Environmental Pollution 146: 299-310. Doi:10.1016/j.envpol.2006.03.023

DuCKetT J. \& PRESSEL S. 2009. London's changing bryophyte flora. Field Bryology 98: 30-46.

Dymytrova L. 2009. Epiphytic lichens and bryophytes as indicators of air pollution in Kyiv city (Ukraine). Folia Cryptog. Estonica 46: 33-44.

Fojcik B., Chruścinska M., Nadgórska-Socha A. \& Stebel A. 2015. Determinants of occurrence of epiphytic mosses in the urban environment; a case study from Katowice city (S Poland). Acta Mus. Siles. Sci. Natur. 64: 275-286. Doi: 10.1515/cszma-2015-0035.

Fojcik B. \& Stebel A. 2001. Struktura ekologiczna i przestrzenna brioflory miasta Katowice. 128 pp. Centrum Dziedzictwa Przyrody Górnego Śląska. Materiały, Opracowania 5, Katowice.

FUDALI E. 1996. Distribution of bryophytes in various urban-use complexes of Szczecin [NW Poland]. Fragm. Flor. Geobot. 41(2): 717-745.
FudALI E. 1998. Investigations of bryophytes in Polish towns - a reviev of the bryological research and data. Fragm. Flor. Geobot. 43(1): 77-101.

FudALi E. 2001. The ecological structure of the bryoflora of Wroclaw's parks and cemeteries in relation to their localization and origin. Acta Soc. Bot. Poloniae 70(3): 229-235. DOI: 10.5586/asbp.2001.030

FudALi E. 2005. Bryophyte species diversity and ecology in the parks and cemeteries of selected Polish cities. 212 pp. Wydawnictwo Akademii Rolniczej, Wrocław.

FUDALI E. 2006. Influence of city on bryophyte floristical and ecological diversity in parks and cemeteries. Biodiv. Res. Conser. 1-2: 131-137.

FudALI E. 2012. Recent tendencies in distribution of epiphytic bryophytes in urban areas: a Wroclaw case study (south-west Poland). Polish Bot. J. 57(1): 231-241.

FudALI E. 2018. Ekspansja epifitycznego mchu Orthotrichum pumilum Sw. na terenie Wrocławia. Fragm. Flor. Geobot. Polonica 25(2): 295-298.

Fudali E. \& Szymanowski M. 2019. Epiphytic bryophytes on alien host tree species in Wroclaw (SW Poland). Cryptogamie, Bryologie 40 (11): 119-129. doi. org/10.5252/cryptogamie-bryologie2019v40a11

Fudali E. \& Wolski G. J. 2015. Ecological diversity of bryophytes on tree trunks in protected forests (a case study from Central Poland). Herzogia 28(1): 91-107. 
Fudali E. \& ŻoŁnierz L. 2019. Epiphytic bryophytes in urban forests of Wroclaw (SW Poland). Biodiv. Res. Conserv. 53: 73-83. DOI 10.2478/biorc-2019-0005

Gamrat R. 2012. Studia nad różnorodnością śródpolnych wysp środowiskowych w dorzeczu Iny. Wyd. Uczelniane Zachodniopomorskiego Uniwersytetu Technologicznego, Szczecin.

KiRmaCi M. \& AĞCAgIL E. 2009. The bryophyte flora in urban area of Aydin (Turkey). International Journal of Botany 5(3): 216-225.

Lewicki Z. (ed.). 2014. Środowisko Wrocławia. 131 pp. Wydawnictwo Lemitor Ochrona Środowiska sp. z o.o., Wrocław.

MeŽAKa A., Brümelis G. \& Piterāns A. 2008. The distribution of epiphytic bryophyte and lichen species in relation to phorophyte characters in Latvian natural old-growth broad leaved forests. Folia Cryptog. Estonica 44: 89-99.

Mirek Z., Piękoś-Mirkowa H., Zając A. \& Zając M. 2002. Flowering plants and pteridophytes of Poland. A checklist. In: Z. MiReK (ed.). Biodiversity of Poland, 1, 442 pp. W. Szafer Institute of Botany, Polish Academy of Sciences, Kraków.

Ochyra R., Żarnowiec J. \& Bednarek-Ochyra H. 2003. Census Catalogue of Polish Mosses. In: Z. Mirek (ed.). Biodiversity of Poland, 3, $372 \mathrm{pp}$. Polish Academy of Sciences, Institute of Botany, Kraków.

Richter S., Schütze P. \& Bruelheide H. 2009. Modelling epiphytic bryophyte vegetation in an urban landscape. J. Bryol. 31: 159-168. Doi: 10.1179/174328209X431277.

SAbovluević M. \& Grdović S. 2009. Bryophyte diversity within urban areas: case study of the city of Belgrade (Serbia). International Journal of Botany 5(1): 85-92.
Schatpae A. 1986. Veranderungen der Moosflora von Berlin (West). Bryophytorum Bibl. 33: 1-392.

Sérgio C., Carvalho P., Garcia C. A., Almeida E., Novais V., Sim-Sim M., Jordão H. \& Sousa A.J. 2016. Floristic changes of epiphytic flora in the Metropolitan Lisbon area between 1980-1981 and 2010-2011 related to urban air quality. Ecol. Indic. 67: 839-852. Doi/10.1016/j.ecolind.2016.03.022.

SienkiewiCz J. 2010. Koncepcje bioróżnorodności - ich wymiary i miary w świetle literatury. Ochrona Środowiska i Zasobów Naturalnych 45: 7-29.

Stebel A. \& Fojcik B. 2016. Changes in the epiphytic bryophyte flora in Katowice city (Poland). Cryptogram Bryol 37(4): 399-414. Doi/10.7872/cryb/v37. iss4.2016.399.

Symonides E. 2010. Znaczenie powiązań ekologicznych w krajobrazie rolniczym. Woda-Środowisko-Obszary Wiejskie 10(4): 249-263.

SzWEYKOWSKI J. 2006. An annotated checklist of Polish Liverworts and Hornworts. In: Z. MiREK (ed.). Biodiversity of Poland, 4, 114 pp. Polish Academy of Sciences, Institute of Botany, Kraków.

Szymanowski M. \& KRYZA M. 2009. GIS-based techniques for urban heat island spatialization. Clim. Res. 38:171187. Doi: $10.3354 / \mathrm{cr} 00780$

VAnderpoorten A. 1997. A bryological survey of the Brussels Capital Region (Belgium). Scripta Bot. Belgica 14: 3-39.

Żarnowiec J., Stebel A. \& Ochyra R. 2004. Threatened moss species in the Polish Carpathians in the light of a new red-list of mosses in Poland. In: A. STEBEL \& R. Ochyra (eds.). Bryological studies in the Western Carpathians, pp. 9-28, Sorus, Poznań. 